\title{
Changes in stimulus envelope reveal two classes of peripheral electrosensory neurons
}

\author{
Michael G Metzen ${ }^{1 *}$, Maurice J Chacron ${ }^{1,2}$ \\ From The Twenty Third Annual Computational Neuroscience Meeting: CNS*2014 \\ Québec City, Canada. 26-31 July 2014
}

Natural sensory stimuli are characterized by time varying moments such as mean (first-order) and variance (second-order). While psychophysical studies have shown that second order attributes (the envelope) are critical for perception, how they are encoded in the brain remains largely unknown. Here we focused on envelope coding by peripheral electrosensory neurons (P-type afferents) in the weakly electric fish, Apteronotus leptorhynchus, using narrowband noise stimuli that where modulated by sinusoids in the frequency range between 0.05 and $10 \mathrm{~Hz}$. Envelopes are an essential feature of natural electrosensory stimuli. When two fish come within close proximity of one another, each animal will experience an amplitude modulation of its own electric signal that oscillates at the difference between the individual EOD frequencies. The envelope varies in time as the distance between two fish changes, and recent studies have shown that it primarily contains low temporal frequencies $(<1 \mathrm{~Hz})$. While primary afferents always increase their firing rates in response to an increase in EOD amplitude, we show that they can either increase or decrease their firing rates in response to an increase in the envelope provided that this increase is greater than their threshold. However, the gain and phase of afferent responses are independent of envelope frequency. Therefore, this study gives important insights as to how neural heterogeneities can influence responses to envelopes and might provide an answer as to why primary afferent baseline firing rates vary over such a large range.

\section{Authors' details}

'Department of Physiology, McGill University, Montreal, QC, Canada.

${ }^{2}$ Department of Physics, McGill University, Montreal, QC, Canada.

'Department of Physiology, McGill University, Montreal, QC, Canada

Full list of author information is available at the end of the article
Published: 21 July 2014

doi:10.1186/1471-2202-15-S1-P191

Cite this article as: Metzen and Chacron: Changes in stimulus envelope reveal two classes of peripheral electrosensory neurons. BMC Neuroscience 2014 15(Suppl 1):P191.
Submit your next manuscript to BioMed Central and take full advantage of:

- Convenient online submission

- Thorough peer review

- No space constraints or color figure charges

- Immediate publication on acceptance

- Inclusion in PubMed, CAS, Scopus and Google Scholar

- Research which is freely available for redistribution
() Biomed Central
C Biomed Central

(c) 2014 Metzen and Chacron; licensee BioMed Central Ltd. This is an Open Access article distributed under the terms of the Creative Commons Attribution License (http://creativecommons.org/licenses/by/4.0), which permits unrestricted use, distribution, and reproduction in any medium, provided the original work is properly cited. The Creative Commons Public Domain Dedication waiver (http://creativecommons.org/publicdomain/zero/1.0/) applies to the data made available in this article, unless otherwise stated. 